\title{
THE SUBSTANTIATION OF ARCHITECTURAL-PLANNING TRANSFORMATIONS OF URBAN PUBLIC SPACES WITH THE ACCOUNT OF THE PRINCIPLES OF BIOPOSITIVITY
}

\author{
Viktoriia Sidorova*, Viktoriia Zhivitsa, Dmitry Mosyakin \\ V.I. Vernadsky Crimean Federal University, Simferopol, Russian Federation
}

This article presents the results of a scientific study conducted within the framework of an intra-university grant. The work was partially supported by the V.I. Vernadsky Crimean Federal University Development Program for 2015-2024. The analysis of the world experience in the design of biopositive public spaces in various cities of the world is considered, the methods for the formation of a sustainable biopositive urban space are outlined in the theoretical works of leading specialists in various directions. Spaces of Crimean cities, in particular its capital - Simferopol, listed a number of problems of the following public urban spaces : areas, landscape objects, pedestrian streets, embankment, etc., formed as a result of the development and growth of the modern city, the results of surveys conducted by the authors (questionnaires, social questions) among guests and local population of Crimean cities. wishes of the residents of Simferopol city, Alushta city and Chernomorskoye settlement to architectural-planning, composition-landscape and artistic expressive qualities of urban public spaces. A short characteristic of the most popular urban spaces is given, their advantages and disadvantages are indicated. The requirements of residents and guests of these the Crimean cities to the qualitative and quantitative characteristics of the material and technical and vegetable content of the urban environment are analyzed. Practical recommendations on the architectural and planning reconstruction of transport and pedestrian units, squares, garden and park facilities, embankments and courtyard spaces, taking into account the principles of biopositivity, are given. Experimental design models are proposed that consider the idea of transforming the existing public spaces of Crimean cities, taking into account modern international standards and information of sociological surveys.

Key words: Sustainable development, Biopositivity, Reconstruction, Case studies, Public spaces

\section{INTRODUCTION}

Public spaces are areas of communication, recreation and entertainment: squares, parks, embankments, pedestrian streets, boulevards, etc. Separately, these elements have repeatedly been the objects of research, their classification is widely known. Public spaces should provide the population with comfortable conditions for life, work, recreation; transfer individual color, the history of the city; and meet the norms and needs of modern society.

At the present time, the general classification of open urban spaces has not yet been adopted. This is due to the complexity of urban facilities, as parts of a system of public spaces, combining a variety of functional, technical and even ideological characteristics.

Issues related to the analysis of public space problems of the Russian Federation were have been dealt with by many architects, town plannersand researchers, including Lagodina E.V. [1], Zhelnina A. [2], Shpakovsky L.L., ChernovaZh. V. [3], Danilova T. [4], Sidorova V., Chubova O. [5], etc. It should be noted that there are a large number of twin cities throughout post-Soviet countries with a typical layout of territory, buildings and street equipment. Despite notable drawbacks of the method of designing the territories of the Soviet period, it has an un- deniable advantage over the modern one - an integrated approach to the territories.

The state in this period of time no longer has such a complex influence on the planning and development of urban areas. Private large developers, investors, entrepreneurs came to the fore. They have also invested in spot development and are not interested in the development of urban public spaces. Preliminary analysis showed that there are many problems that need to be addressed. This study is particularly relevant for the urban development of the Republic of Crimea, for the promotion of tourism and improving the quality of life of the local population.

The purpose of the study is to identify the characteristic problems and shortcomings of modern public spaces of Crimean cities and to provide practical recommendations for their reconstruction and improvement, taking into account biopositivity.

\section{Main objectives:}

1. To conduct and systematize complex full-scale surveys of public spaces in Crimean cities, to make photo fixation of problem areas.

2. To process the results of public opinion polls.

3. To present the results of comparative analysis of the world experience in the development of public 
spaces, to identify the main trends.

4. To give recommendations on the reconstruction of public spaces of the Republic of Crimea.

Public works of foreign authors were devoted to the study of public spaces: Zukin Sharon [6], Letícia Peret Antunes Hardt, Carlos Hardt [7], Joana Carla Soares Gonçalves [8], AdrianoMagliocco [9].

Many of the world's scientists are engaged in issues related to the concepts and principles of biopositivity, sustainable urban development, energy efficient architecture, including the leaders of countries: A.N. Tetior [10], G.V. Esaulov [11], Jan Gale [12], Lee Kuan Yew [13], Henri Lefevre [14], Colleen Ellard [15] and many others. The analysis of publications made it possible to confirm and consolidate the opinion that cities can be more environmentally effective and sustainable if modern technologies are used in the improvement of the urban environment.

\section{MATERIALS AND METHODS}

Within the framework of this research, scientific literary works were studied: dissertations and authors' abstracts, textbooks, monographs, books, legislative and regulatory framework; the permanent monitoring of the materials of periodicals of domestic and foreign authors corresponding to the research topic was conducted.

In studying the world experience in the design, construction and reconstruction of urban public spaces, theoretical general scientific methods were used: comparative analysis, analogy, deduction and induction methods, generalization,

To collect information on the existing urban planning situation in Crimean cities, full-scale surveys, architectural measurements, and photographic fixation were undertaken.

Sociological surveys and questionnaires were conducted to identify the architectural, planning, artistic and aesthetic, sanitary and hygienic qualities of the Crimean city public spaces with modern world standards and expectations of residents and guests of the Crimea. The respondents expressed their opinions by completing questionnaires on the Survio website, as well as the questionnaires in the printed version. When processing the results of sociological research, we used: classification, comparison, statistical analysis, systematization of graphs, diagrams, tables and charts constructed according to the results of polls.

In the process of creating architectural projects and proposals for the restoration, reconstruction and transformation of urban public spaces (see Figures 11-16), scientific forecasting and experimental modelling were used.

Variants of architectural and spatial solutions and material and technical content of urban public spaces are proposed on the basis of sociological research data and careful analysis of the urban development situation.

The results, conclusions and recommendations outlined in the article are universal. They can be applied to any urban public space, and can be used to create and optimize modern building codes and regulations.

\section{RESULTS AND DISCUSSIONS}

To prepare recommendations for the reconstruction of public spaces, the most successful and attractive cities in the world were analyzed: Vienna (Austria), Zurich (Switzerland), Auckland (New Zealand), Melbourne (Australia), Barcelona (Spain), Vancouver (Canada), Dusseldorf (Germany), etc. [16].

Despite a huge number of different architectural and planning solutions, it is possible to identify common characteristics for all attractive urban public spaces. All of them are: open, accessible and safe for visitors, convenient in many ways, attractive (from classics to modern art), aesthetic satisfaction and interest, these spaces are multifunctional and allow you to choose different ways of pastime, promote new acquaintances and communication of visitors.

The most interesting public spaces reflect the history of the city in which they are located and represent the quintessence of local traditions and customs [17]. Many modern public areas are saturated with environmentally eco-friendly (biopositive) materials and technologies that promote sustainable development of the settlement, which is extremely important in the context of global urbanization.

Currently, a promising model of public space is a dynamic, transforming form.

Depending on the type, image, planning organization, style and general state, public spaces exert a significant influence on the behavior, emotions, perception of the city by its inhabitants.

Thus, there are different models of spaces that determine the behavior of users. When a person walks down the street, with inexpressive buildings, he tries to depart this space as quickly as possible. The presence of a variety of functional areas, different options for hanging out, bright architectural accents and unusual small architectural forms arouse interest, increase activity andadd cheerfulness to human movements. Many scientists of different branches of science have dealt with the psycho-emotional impact of architectural environment on people; in particular,Ellard C. in his work [15] described a number of interesting experiments, experiments and observations.

Full-scale studies of public spaces in Simferopol made it possible to identify a number of problems, as well as to analyze practical and experimental ways to solve them.

We note the most significant problems: material and technical deterioration and dilapidation of urban equipment; low level of improvement of public spaces; loss of decorative and aesthetic and sanitary-hygienic properties of garden and park facilities; ubiquitous application of typical small architectural forms, lack of recreational 
areas for recreation; an extremely low degree of introduction of biopositive technologies, etc. A large problem is the massive building of public spaces with temporary or capital buildings and structures: in connection with the high cost of land, they prefer to build shopping centers, residential and office buildings instead of comfortable urban public spaces. These problems are relevant in one way or another for all major cities.

Below is an analysis of the most characteristic problems in the territories of urban public spaces in Simferopol.

\section{Embankment}

The Salgir River is the main waterway of Simferopolcity. Along the embankment, there are garden and park spaces of common access: Yuri Gagarin Park, Children's Park, N.V. Bagrov's Botanical Garden. Square Mir and others. In the complex, all garden and park facilities should constitute a continuous green frame of the city. Unfortunately, at present, the river and the surrounding areas are in unsatisfactory condition.

Architectural and town-planning problems of Simferopol's city embankments. The riverbed is silted. Engineering equipment is physically and morally obsolete. On some sections of the embankment, there is no fence. They require repair: covering of pedestrian paths, construction of bridges, observation platforms. It is necessary to replace outdated garden and park furniture: pergolas, canopies, benches, urns, etc. Weakly developed recreational infrastructure. There are no standard bike paths, bicycle parking, bicycle rental; there are no tracks for running. Not enough well-equipped zones for various purposes near water: mini-scenes, playgrounds, playgrounds, sports zones. There are no specialized grounds for walking and training dogs. There is an insufficient amount of evening lighting and lack of decorative illumination of the territory along the embankment.(Figure 1).

\section{Green areas of the city}

In Simferopol, the boundaries and areas of parks are reduced in connection with the construction of green public zones (Figures 2, 3). For example:

- within the perimeter of Yuri Gagarin Park there


Figure 1: The embankment of the river. Salgirin Simferopol City requires repair and reconstruction

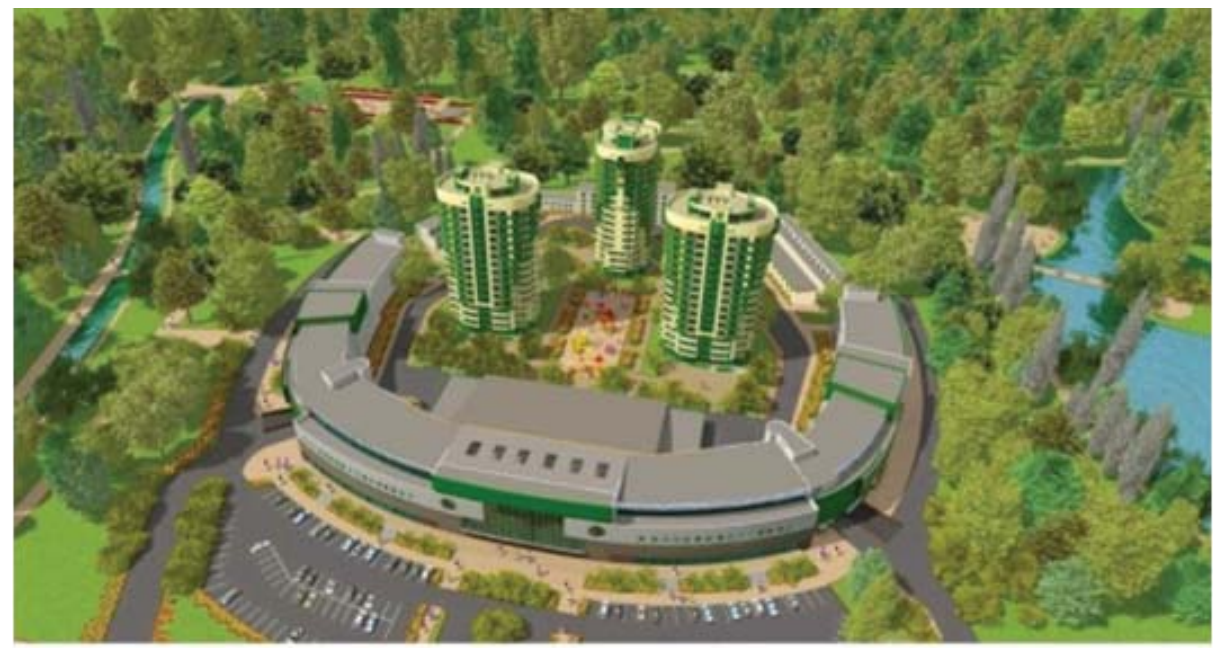

Figure 2: Buildings in the parks named after Yuri Gagarin 
were built: the hotel-restaurant "ChistiyePrudy", the multi-apartment residential complex "Gagarinsky", the Gagarinsky shopping center, the Ice palace "Console-Sport", parking lots for the visitors of these objects (Fig. 2);

- in T.G. Shevchenko's Parkwas built a chapel, and since 2010 the construction of a 3-storey building has been conserved (Fig. 3);

- In the Park "Salgirka" is built up the territory of multi-apartment buildings [18]. The most significant problems of garden and park facilities in Crimean cities are: the lack of constant care for green spaces and equipment, litter of territories and an outdated material and technical fund.

The city areas of Simferopol city also need reconstruction and development. There are 8 main squares in the city. The main square - Lenin Square - is the only place for holding various mass events. But it accommodates no more than 3500 people with the number of the resident population of the city of 341,799 people (as of January 1, 2018) [19]. In the Lenin Square there

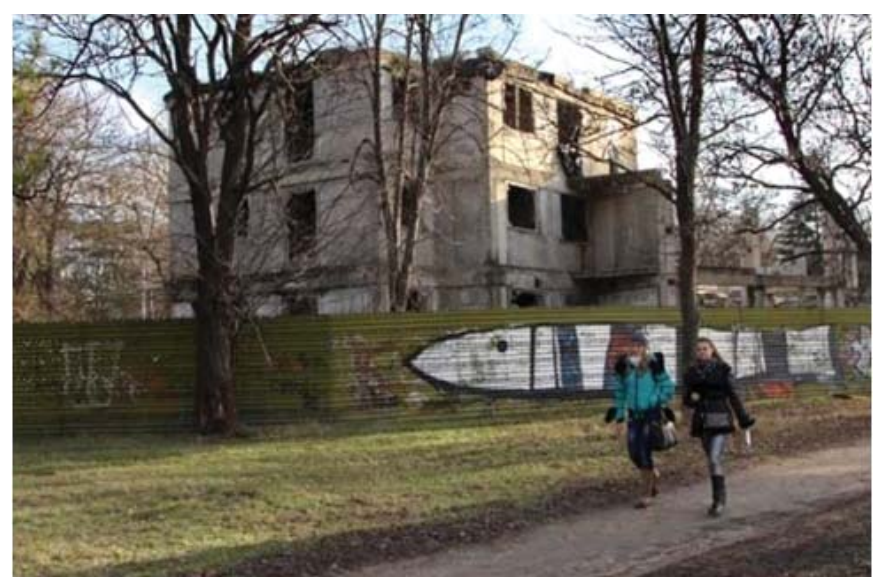

Figure 3: Development in the park named after T. Shevchenko

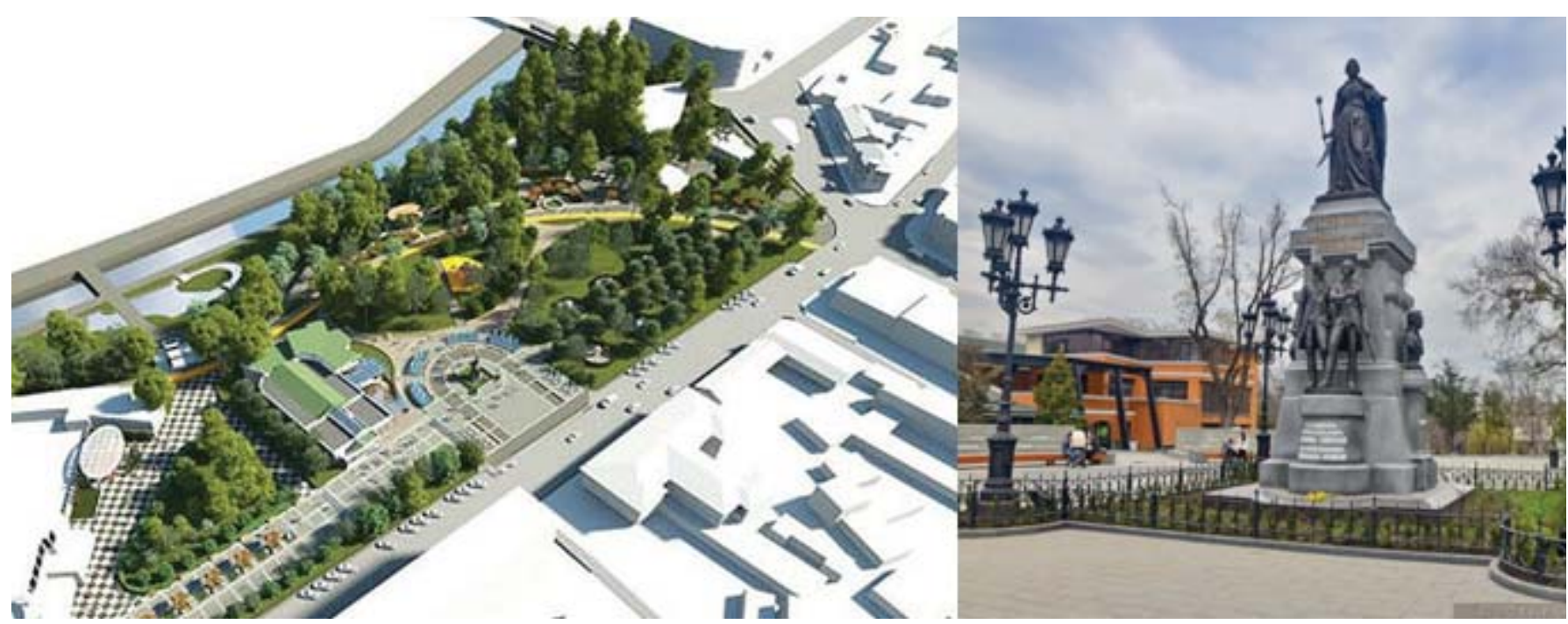

Figure 4: "Catherine's Garden", reconstruction of 2016 is no sun protection and wind-protection equipment. The numbers of benches for rest, garbage cans, lighting devices does not correspond to the norms and needs of residents. Modern information technologies and the Internet are not used. Commercial and transport areas (Kuibyshev Square, Moskovskaya Sq.) are inconvenient for pedestrians, need improvement and clearance from temporary trading and capital buildings and structures. Transport areas (the area of the Soviet Constitution and the Railway station square) need to solve thecirculation problem with pedestrian crossings. Ground pedestrian crossings are unsafe. They inhibit traffic, creating traffic jams.

Part of the above problems are solved by the city government and the indifferent citizens of the city. However, the majority of architectural and town-planning solutions are of a unified nature. Concurrently, new problems arise.

In accordance with the "Strategy of social and economic development of the municipal formation of Simferopol city in the period until 2030" it is planned: [20].

1. To agree a unified architectural style for all new buildings and facilities.

2. To develop public spaces taking into account the needs of all categories of the population: children, adolescents, adults, elderly and less mobile citizens.

3. Create public areas not only in central, but also in residential areas.

4. Make convenient and understandable navigation around the city and public areas, etc.

This is only part of what is theoretically planned for the provision of comfort in public spaces.

It should be noted that Crimea is a unique territory, rich in traditions of different peoples and cultures, and the region is diverse in its innate and climatic characteristics. Therefore, it is inexpedient to create a single style for all public spaces. Each city and even an area can have its own characteristics, and for this it is necessary to 
take into account a multitude of factors whose influence should be reflected in the architectural-planning and landscape-decorative component of each newly created or reconstructed public space.

Ekaterininsky garden. In 2014, on the eve of the 230th anniversary of the city of Simferopol, the authorities planned to fully update the appearance of the Central Park and reconstruct the idle fountain complex. In 2016, at the site of the fountain complex, a large-scale monument was erected to the founder of the city of Simferopol, the Russian Empress Catherine II (Figure 4).

In the park near the monument to Catherine II, on the site of the "Green Theater", a hotel was built, the inadmissibility of the opening of which was spoken by the administration of Simferopol.

In 2017 the area of the park was reduced by 1.366 hectares to 4,082 hectares.

Children's park. In the period from 2011 to 2014 , a largescale reconstruction of the park was carried out: the "Glade of Fairy-Tales" was updated, new benches were installed, evening lighting and decorative illumination of the central alley were installed, all rides were repaired. In 2014 , the central entrance of the park was reconstructed. In July 2017 , local authorities reduced the area of the park from 17 to 10 hectares (Figure 5).

The "Republic" square was opened in 2013 on the site of the former Astoria hotel. There are several functional zones on its territory: a children's playground, a quiet

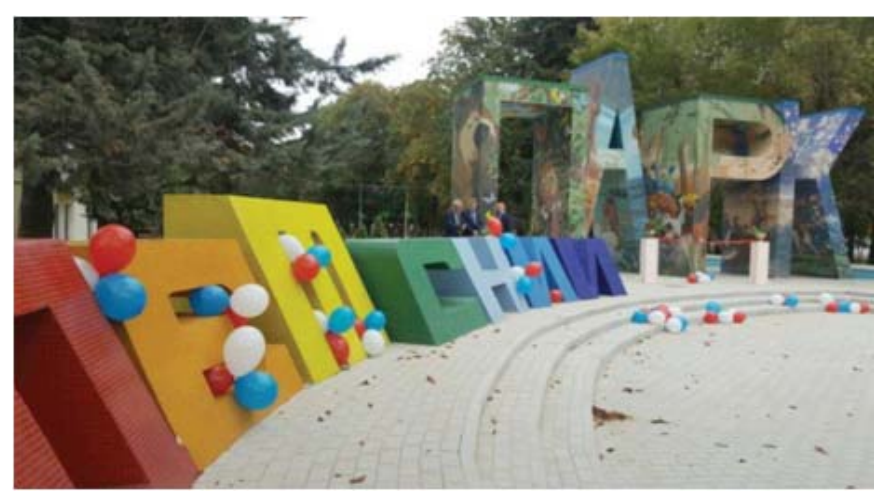

Figure 5: Central entrance to the territory of the Children's Park, Simferopol

rest area, a zone for holding mass events (Figure 6). In this work, as a method of scientific research, a sociological survey was used to identify the problems of the issue under study and to predict the desired results. Within the framework of the work, 2 public opinion polls were conducted among the local population of the Crimea. We also consider it appropriate to take into account the materials of other sociological surveys conducted earlier and previously published on public spaces [21]. Their generalized results can be useful and applicable to other cities with a predominant business function (for example, Simferopol [22]) and a resort function (for example, Alushta [23], Chernomorskoye).

Let us consider the most important and significant results

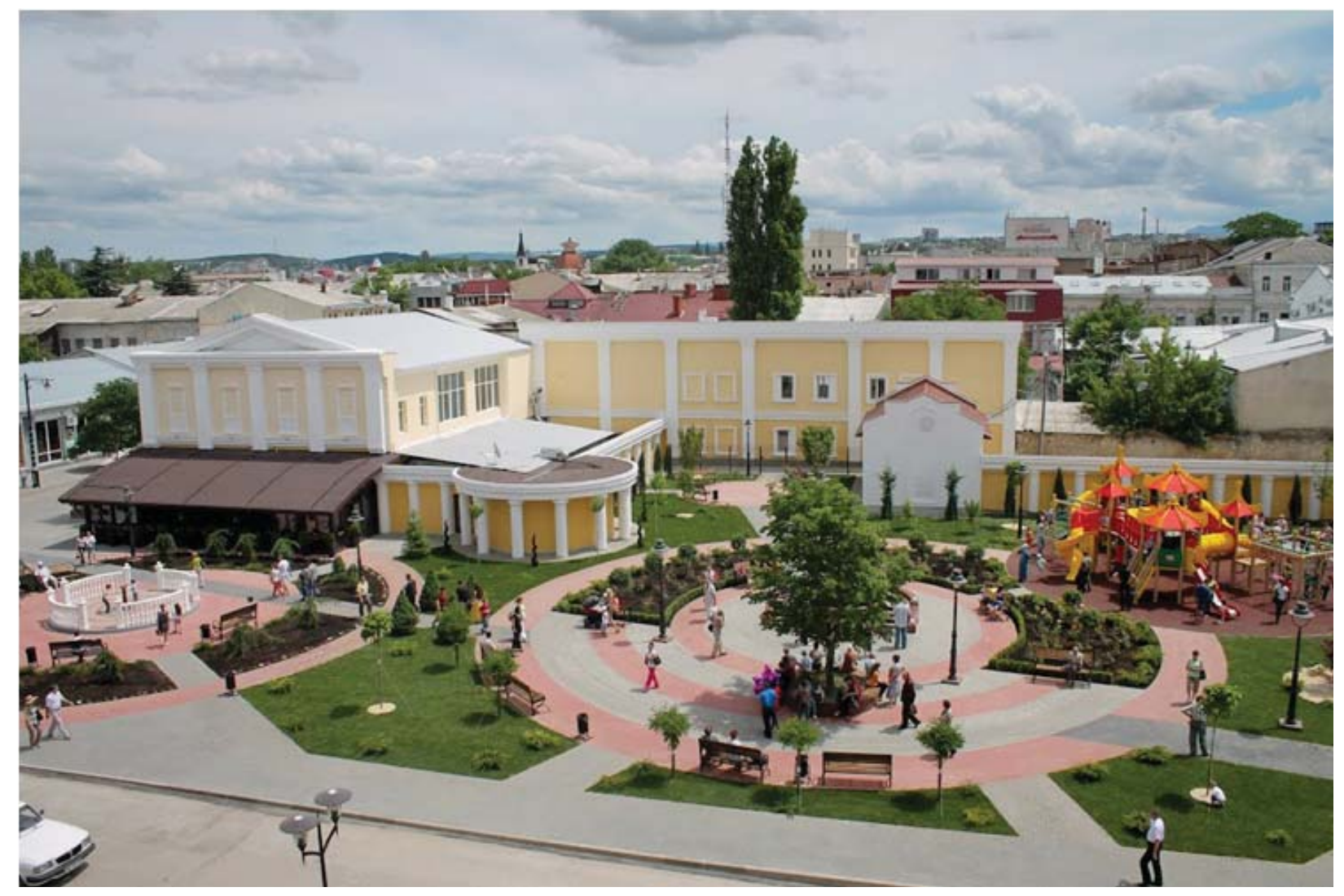

Figure 6: Republic Square in Simferopol 


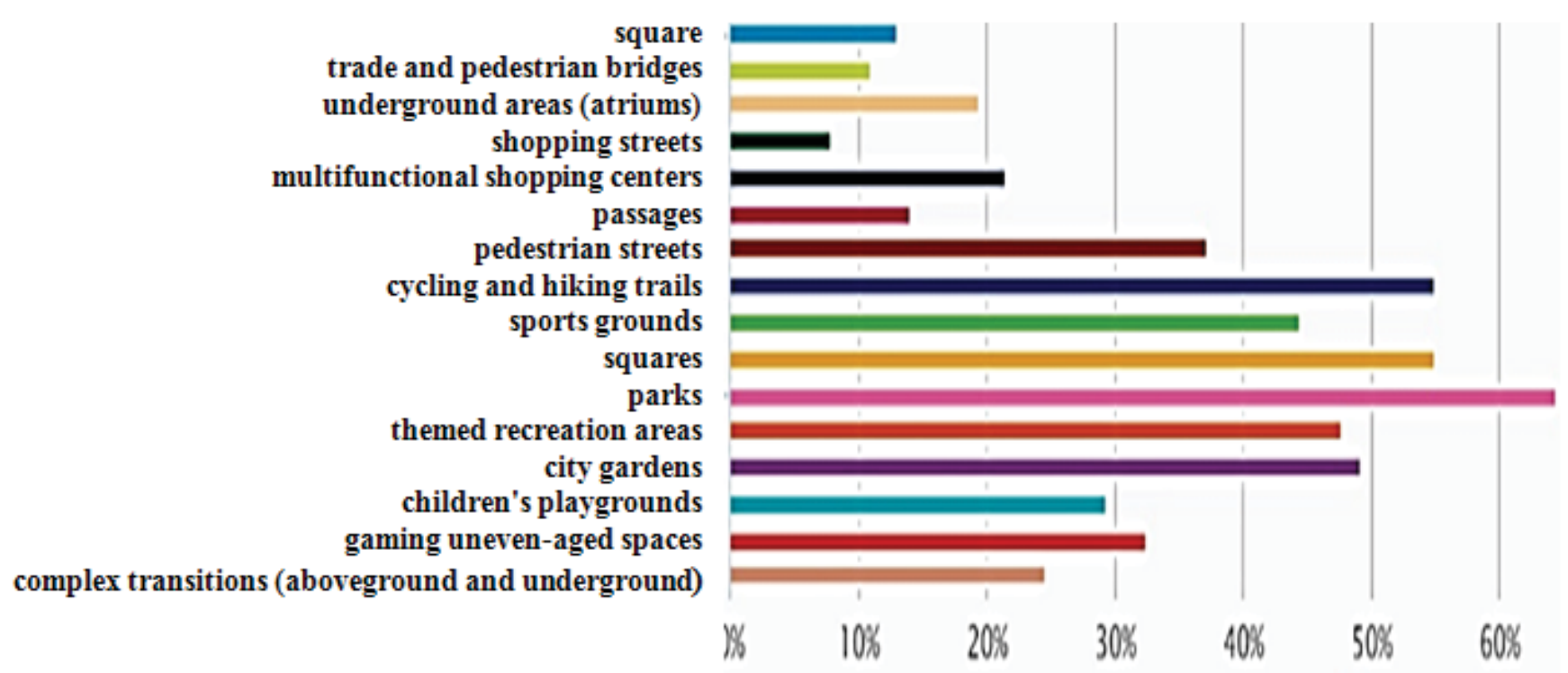

Figure 7: The result soc. poll: "Which of the following public spaces would you like to see additionally in Simferopol?"

of sociological research.

In the survey "Public spaces and urban environment" (Electronic voting system Active Simferopol), 1400 people took part in the public spaces of Simferopol [21]. 98\% of respondents consider public spaces to be the most important element of the urban environment, the state of which seriously affects the life of the population. 53\% are interested primarily in the development of the green zones of the city. $78 \%$ of respondents said that the level of landscaping in Simferopol is inadequate. In general, $78 \%$ of the respondents supported the creation of bike paths in the city. Respondents expressed negative attitudes on the issue of multi-storey dense building of the city; on the situation with a large amount of public transport in residential micro-districts. They also pointed to the negative trend of the placement of personal vehicles in the public areas of residential yards, along city roads and in the territories of public spaces.

The results of the social survey "Public Spaces in Simferopol" [24] showed the following results. A positive fact was that young people between the ages of 22 and 35 have an active attitude and are very interested in the development and popularization of public spaces.

To the question: "Which of the following public spaces would you like to see additionally in Simferopol?" (Figure 7 ) - the majority of the respondents answered "garden and park facilities" (parks, sports grounds, bike and hiking routes, urban gardens).

As you can see, the townspeople need green areas, public spaces, where you can hide from the noise, dust and city bustle. As you know, a person is comfortable in nature, in such an environment a person feels lighter, his psycho-emotional state and overall well-being improve. In the urban environment, residents are less likely to want to see various trading institutions, perhaps this is due to the fact that the city is significantly oversaturated by these facilities. The majority of the respondents (75\%) believe that in Simferopol the transitions (both aboveground and underground ones) are unsatisfactory. Fullscale surveys also confirm this fact:

- $\quad$ the marking of ground pedestrian crossings, leading

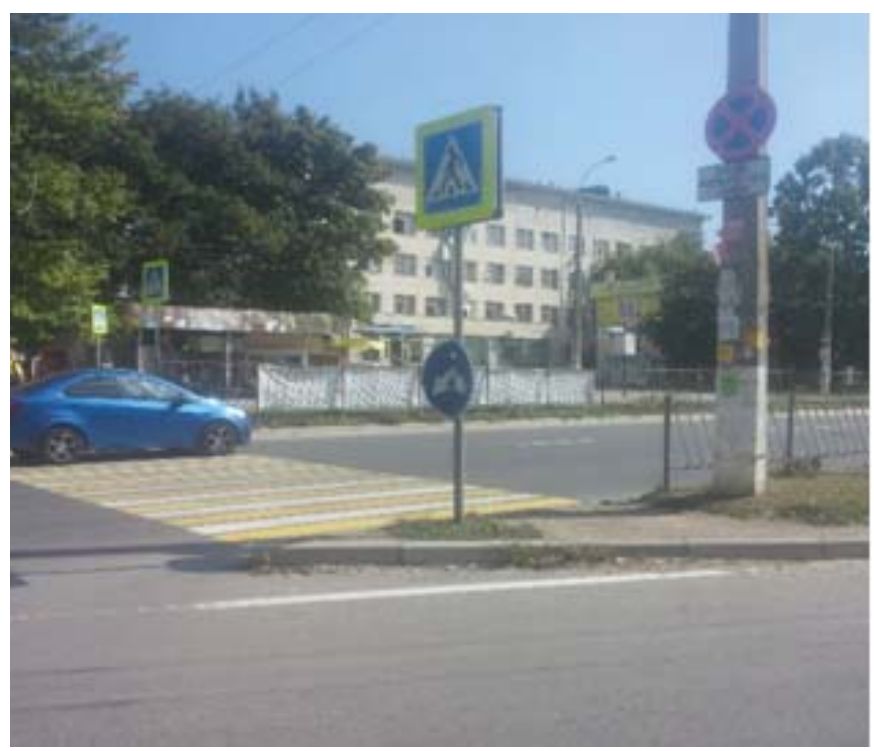

Figure 8: Pedestrian crossing on the street 60 years of October (city hospital)

to the green strip, and not to the sidewalk (on the street of Balaklava, street 60 years of October) is shown (figure 8);

- Underground transitions are poorly lit at night, not equipped with ramps, and are places of spontaneous and stationary trade, which hampers the transit passagehamper circulation (Figure 9).

This fact suggests that there is little or no pedestrian in- 


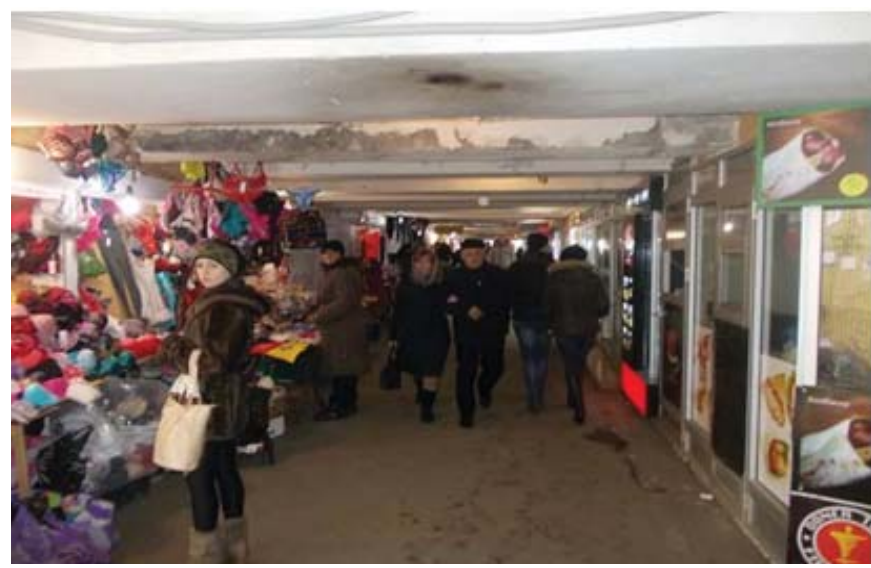

Figure 9: Underground passage in Simferopolcity

frastructure in cities; the needs of low-mobility groups of the population are not taken into account, there are no convenient transitions, and car traffic is organized irrationally.

Also, a bad condition was reported in: city parks $(68 \%$ of respondents), sports grounds (56\% of respondents), public gardens (53\% of respondents), children's playgrounds ( $49 \%$ of respondents), urban areas (36\% of respondents).

The organization of the urban environment should be designed for a long stay of a person outside the home, office, educational institution. People want to feel comfortable in the city: in a park, on a square or a pedestrian street. But at the present time most of the settlements do not have the time to spend in the urban environment. So the majority of respondents believe that the city's infrastructure facilities are in unsatisfactory condition. The city is practically not adapted for people with disabilities and women with children and wheelchairs. The townspeople want to see the urban environment progressive and evolving, they dream of living in a modern ecological and technological city.

The level of improvement of public spaces was noted by respondents, as unsatisfactory $-56 \%$, satisfactory $-41 \%$.

Thus, to create a comfortable urban environment, it is necessary to reconstruct the existing infrastructure.

Among the large list of street equipment offered for the comfort of the urban environment, the respondents identified the following as the most necessary for additional accommodation: garbage bins (74\%) public toilets $(71 \%)$, benches $(70 \%)$, flower beds and flower beds $(69.6 \% \%)$, lanterns $(68.1 \%)$, arbours $(52.9 \%)$, shady canopies (44.5\%), fountains (54.5\%). Also, $55.5 \%$ of the respondents noted problems with storm sewage and water disposal.

$64.4 \%$ of the respondents confirmed that it is necessary to improve the River Salgir. $66.5 \%$ of respondents believe that the city lacks gardening and it is necessary to plant new shrubs, trees, to arrange flowerbeds and lawns.

$95.8 \%$ of respondents noted the need for the additional equipping of public spaces with ecological, biopositive technologies and materials. They answered in the positive to the question: "Should the following modern technologies be used in urban areas: solar panels $(30.4 \%$ of respondents), universal chargers for mobile devices (41.4\% of respondents), free Internet (80\% of respondents), electronic signposts (33.5\% of respondents), tourist maps-scoreboard (38.7\% of respondents) ".

The level of transport and pedestrian accessibility from places of residence and work to public spaces was estimated at 3.1 points (out of a possible 5 points).

The object of the next survey was a public garden near the Moscow Ring in Simferopol. For $69 \%$ of those polled, the square performs a transit function. Respondents chose the following most important criteria for reconstruction: a single architectural style for small architectural forms $(99 \%)$, ease of use (99\%), high-quality materials $(96 \%)$. The majority of the respondents noted that it is necessary to place extra: benches, garbage bins, a system for separate collection of waste, solar batteries and electronic devices that work from them - lighting devices, recharging devices; Wi-Fi, children's play and sports grounds, public toilets, gazebos and shady canopies, fountains and sculptures. All respondents believe that in the reconstruction it is necessary to create a barrier-free environment for the less mobile groups of the population.

In the spring of 2018, within the framework of the contest "Models of living cities", two sociological surveys were conducted on two public spaces in the resort town of Chernomorskoye: "Improvement of the South Street" and "Improvement of the commercial area".

The results of the questionnaire analysis showed that local residents are interested in improving the functional and aesthetic qualities of these territories. The following desirable transformations were noted for the modernization of the trading area: install garbage bins (33\%), benches $(34 \%)$, add landscaping (39\%), combine trade pavilions (53\%) with a single architectural style, add vases and sculptures $(23 \%)$. Respondents also noted the need to replace worn tiles and the installation of ramps. Young people showed a great desire in locating here an equipped skate park.

In a survey on street reconstruction, $62 \%$ of respondents noted that, for them, functionality and individual design in the improvement of public spaces are important $(32 \%$ of respondents). Thanks to the survey it was possible to find out that $66 \%$ of local residents considerthere to be insufficient amount of landscaping on the street. South. Below is a graph of the necessary elements for the representation of the villagers of the elements of gardening (Figure 10).

The residents additionally indicated that it is necessary to place more children's and sports grounds in the yards of apartment housesand to systemize the parking of private cars. 


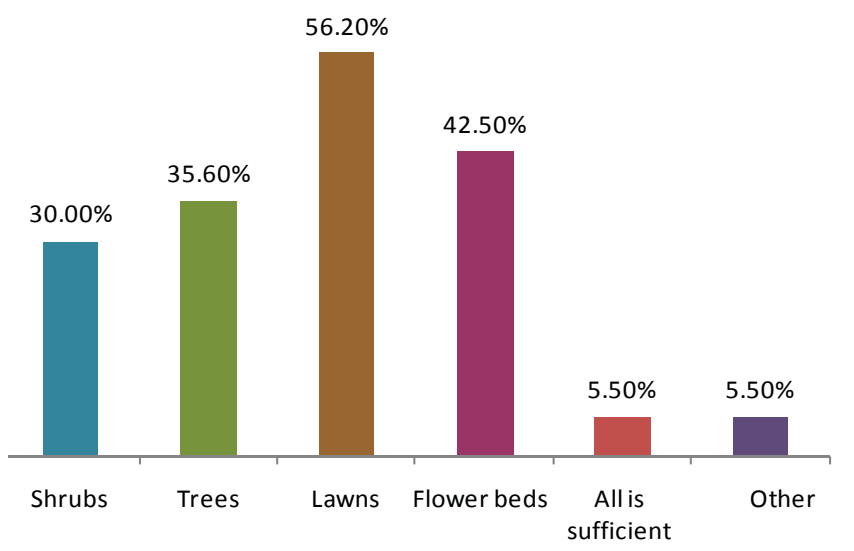

Figure 10: Results of social poll: "Missing elements of gardening st. South "(Chernomorskoye settlement)

According to the results of sociological research, it can be argued that, despite the individuality of each city, the problems of architectural and planning organization and the material and technical content of public spaces, as well as the needs of residents and guests of various settlements in the Crimea are similar in many respects and, in general, correspond to world trends and norms.

In the framework of educational disciplines "Reconstruction of town-planning objects", "Reconstruction of garden and park facilities", as well as for participation in regional and all-Russian competitions, experimental design models for the transformation of public spaces in various cities of the Crimea were developed.

The students prepared several experimental design models for the reconstruction of seaside embankments (Fig. 11, 12, 13); squares and traffic junctions (Figures 14, 15), parks, squares and other green zones (Fig. 16). All sketches are made taking into account the needs of the permanent and temporary population according to the principles of biopositivity (benefit, convenience and environmental friendliness).

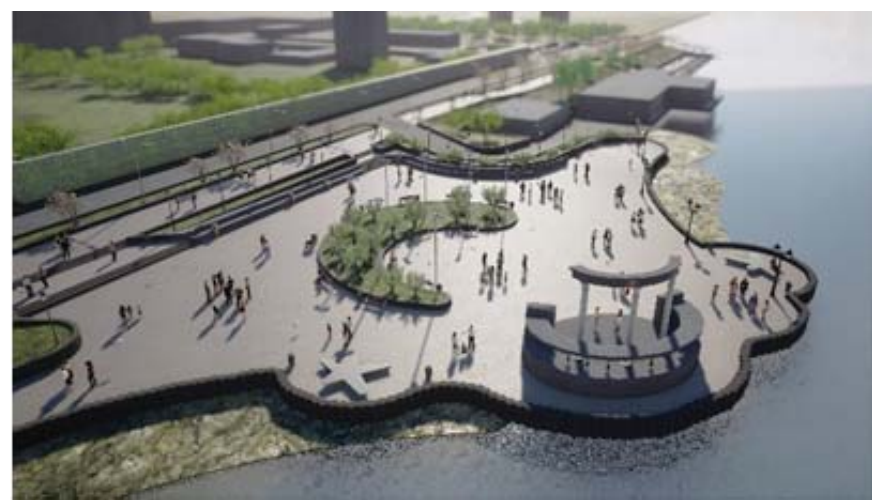

Figure 11: Sketch proposal for the reconstruction of Suvorov redoubt and st. Embankment in the village of Chernomorskoe; authors: Dmitriev I., Soltys V., head: Yakovenko N.E., Zhivitsa V.V.

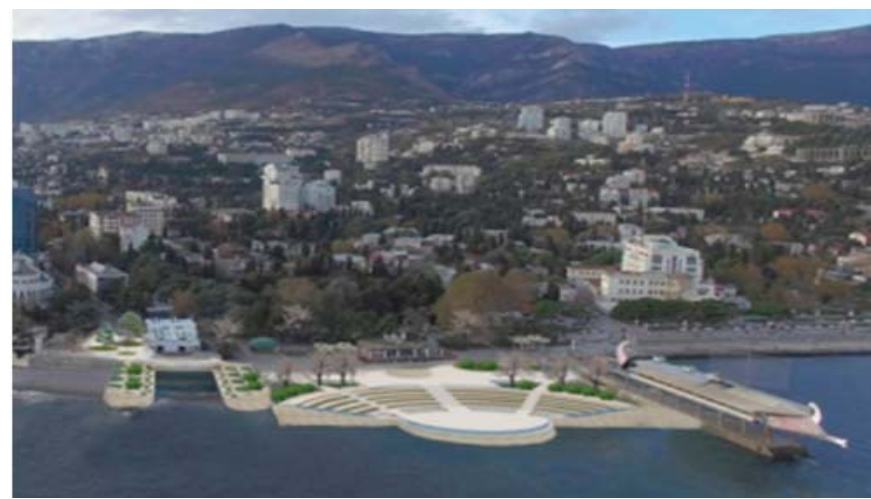

Figure 12: Embankment of Yalta; authors: Alekhina E., Kurkovich K., Plokhikh A., Minus E., Tiunova M.; head Zhivitsa V.V.

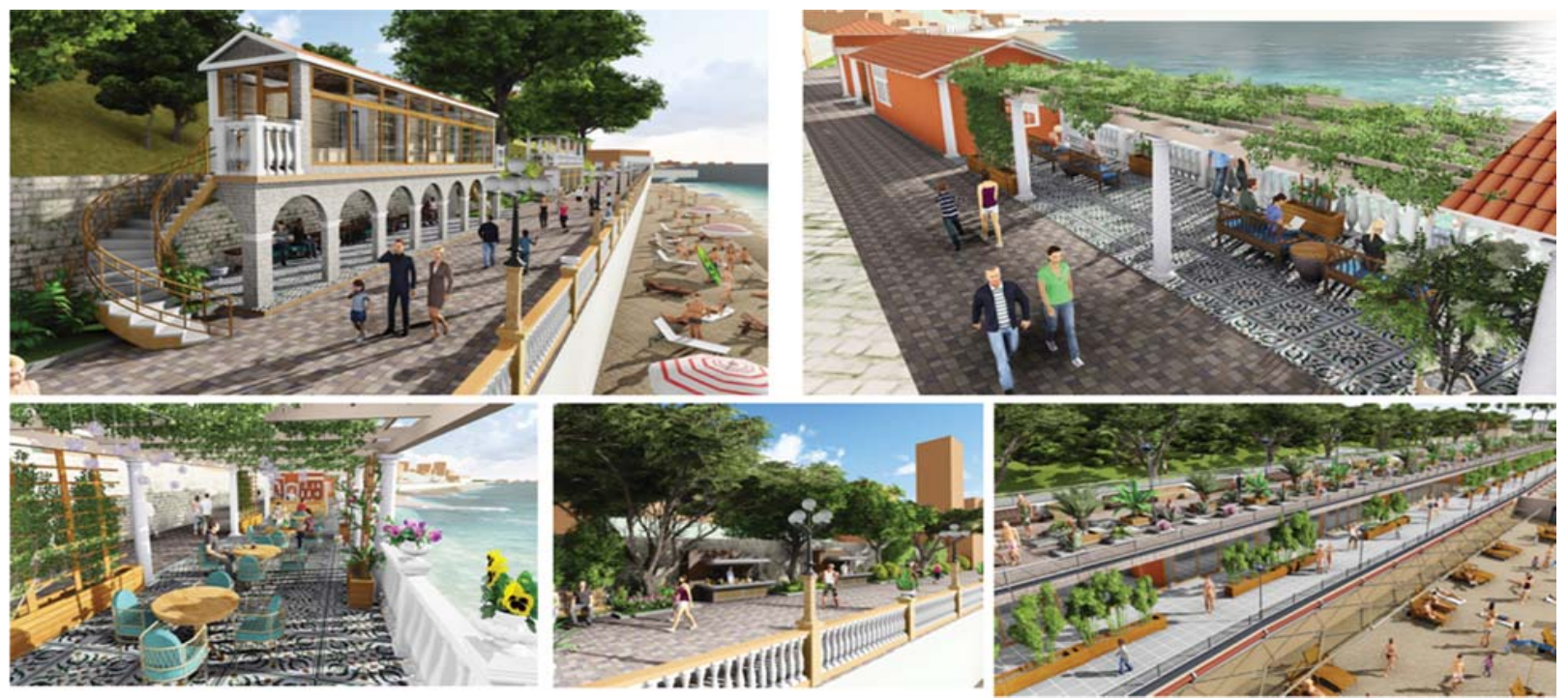

Figure 13: Fragment of the embankment in Yalta; author:Goenko M.; head: Sidorova V.V. 


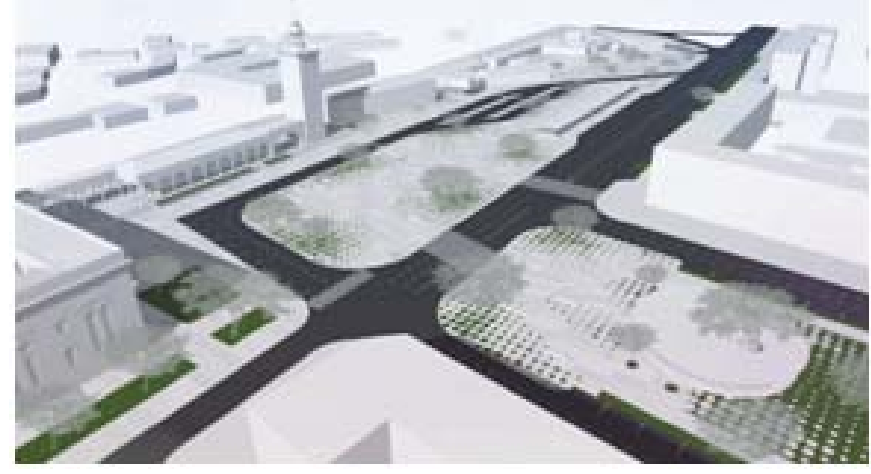

Figure 14: Reconstruction of the station square in Simferopol, author: Kuprienko K.; head: Sidorova V.

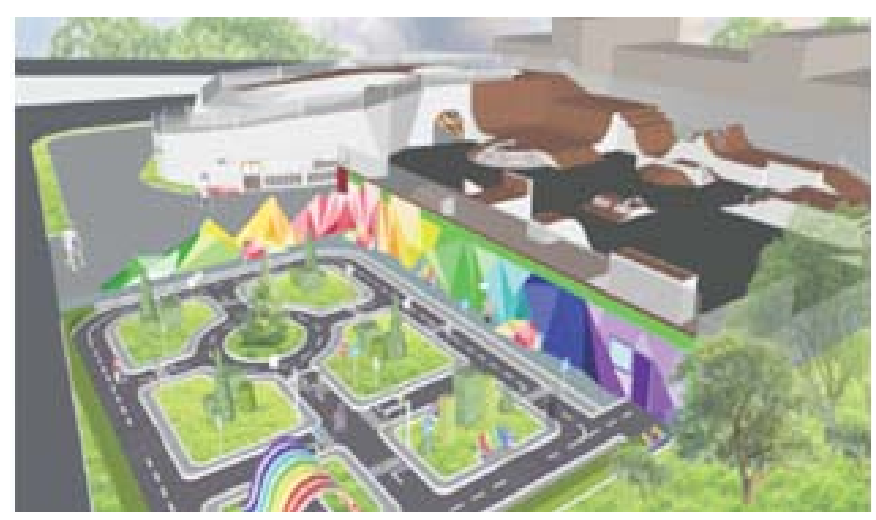

Figure 15: Sketch proposal of the ramp-park, author: Chaschina K.; head: Sidorova V.
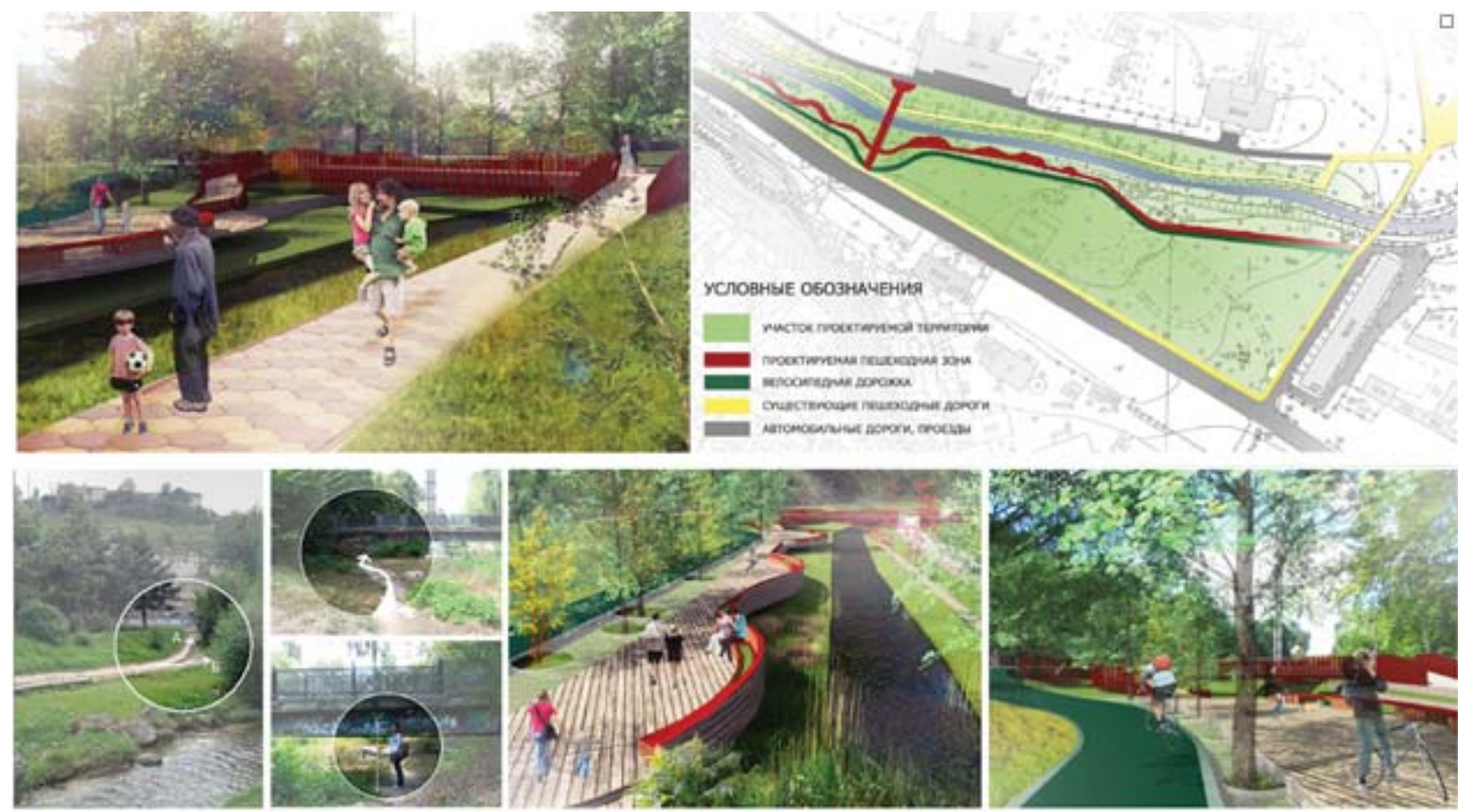

Figure 16: A sketch proposal for the reconstruction of a fragment of the embankment of the Salgir River (author: StekhinaA., head: SidorovaV.)

\section{CONCLUSION}

Public spaces of Crimean cities have a significant unrealized potential. Despite the steady trend of development of territories without the required development of infrastructure and improvement, in Russia there are excellent examples of the development of large public spaces (Zaryadye Park in Moscow, a park in Krasnodar, etc.). Sociological studies have shown that the inhabitants of the Crimea want to study, work and live in a comfortable urban environment and at the same time be closer to nature.

We hope that measures for improvement will soon be adopted in all the settlements of the Crimea. Comfortable public spaces are places for gathering residents and visitors of the city. Also, a well-developed urban environment positively influences the development of busi- ness. The success of the city's economic growth directly depends on the quality of the urban environment, which is characterized by: the availability of convenient transport and pedestrian connections, a high density of development with various types of functional use.

In the absence of interesting and comfortable urban public spaces, people prefer spending more time at home or in large shopping centers. This negatively affects the quality of rest, health and communication. The city lives when its streets are full, parents and children are walking in parks, and young people spend their time on sports, cultural or creative grounds.

Cities urgently need public spaces, which can be transformed depending on the time of year, festive events, taking into account the needs of different age groups. It is necessary to use cultural, historical, creative resources to create the uniqueness and individuality of 
the city. Urban infrastructure must take into account the diversity of the needs of children and parents.

It is recommended to separate public spaces with contrast functions. In the transit space, it is necessary to create places for island recreation and to fill in functional pauses. For the city it is important to use the ability of architectural means to serve as distinctive signs of the place.

Urban spaces should develop the image of the city so that people will want to stay in cities without going to more attractive ones.

Summarizing, it should be noted that competent investment in public spaces of cities is very promising and justified for any city. As for the cities of the Republic of Crimea, they are simply necessary to improve the comfortable living of the local population, attract tourists, individualize and create a unique color of public spaces in different cities, depending on the natural and climatic, cultural, historical and existing urban conditions.

\section{REFERENCES}

1. Lagodina E.V., (2013). The present and future of Russian public spaces. Russian psychological journal, 10, 62-69. Preuzetosa https://cyberleninka.ru/ article/n/nastoyaschee-i-buduschee-rossiyskih-obschestvennyh-prostranstv

2. Zhelnina A., (2011). "Here as a museum": a shopping center as a public space. Laboratorium, 48-69.

3. Shpakovskaya L.L, V.(. (2017). A city friendly to the family: a new public space for children and their parents. Monitoring of public opinion: Economic and social changes, 160-177.

4. Danilova T., (2012). Competition for the Elements of the City Environment for Irkutsk's Public Spaces: Street Furniture, Street Design. Project Baikal.. Architecture, City and Environment, 20-21.

5. Sidorova V., C. (2017). A Comprehensive Approach to the Reconstruction of Open Areas within the Curtilages of Multi-Storey Residential Buildings Built in 1970-1990-th.. Architecture and Modern Information Technologies, 200-214. Preuzetosa http://marhi.ru/ eng/AMIT/2017/3kvart17/15_sidorova-chubova/index.php

6. Zukin Sharon, (. (2013). After the World Trade Center: Rethinking New York City. New York: Routledge.
7. LetíciaPeretAntunesHardt, (. (2007). Historical context of interventions in the landscape and in urban spaces. Paisagem e Ambiente, 101-107.

8. Joana Carla SoaresGonçalves, (2007). Environment, energy and sustainable design: buildings and urban spaces. Pós: Revista do Programa de Pós-GraduaçãoemArquitetura e Urbanismo da FAUUSP, 232-237.

9. Adriano Magliocco, (. (2014). Urban environment and vegetation: comfort and urban heat island mitigation. Techne : Journal of Technology for Architecture and Environment, 155-162.

10. Tetior A.N., (2008). Architectural and construction ecology. Moscow: Academy.

11. Esaulov G.V., (2014). Sustainable architecture from principles to development strategy. Vestnik of TSUAB, 9-24.

12. Jan Gehl, (2012). Cities for People. Moscow: AlpinaPablisher.

13. Lee Kuan Y., (2005). Singapore's history. Moscow: MGIMO (U) MFA of Russia.

14. Henri Lefèvre, (2015). Production of space.

15. Colin Ellard, (2017). Places of the Heart: The Psychogeography of Everyday Life.

16. https://mobilityexchange.mercer.com/Insights/quality-of-living-rankings

17. https://city4people.ru/post/blog_583.html

18. https://ru.krymr.com/a/photo/28793639.html

19. http://города-россия.pq/sity_id.php?id=

20. https://evp.rk.gov.ru/ru/structure/465

21. http://xn--80aejkbfenhhpammII5bzi4a.xn--p1ai/ poll/508

22. Sidorov V. V., D.(. (2017). On the necessity of forming a network structure of a multifunctional youth centres.. Bulletin of the South Ural State University. Series "Construction and architecture." Urbanism and architecture., 17, 5-14.

23. Sidorova V.V., (2011). Sociological research on coastal areas. Modern problems of architecture and urban planning: Nauch.-Tekhn. compilation., 267275.

24. https://www.survio.com/survey/d/C4T2T4H6S7F4T4R3P

Paper submitted: 10.09.2018.

Paper accepted: 25.03.2019.

This is an open access article distributed under the CC $B Y-N C-N D 4.0$ terms and conditions. 